\title{
FAKTOR-FAKTOR PENGGUNAAN STUKTUR RANGKA BETON DAN STRUKTUR RANGKA BAJA
}

\author{
Wulan Tisahyuning Tyas, MOS Aritonang, Winoto Hadi
}

\begin{abstract}
Considering of structure plan consultants decision of what kind of structure will they use is different depend on their skill and experiences. Goodness and badness of concrete and steel frame work become factors that influence to their decision.
\end{abstract}

The method that they use to get information about factors that influence structure plan consultants for deciding of what kind of frame work will they use, find in three steps, first with interviewing with the respondents, second with literature studying, and third with spreading the questioners.

The result of this research are $63.45 \%$ of respondent said that the ten variables that serve in this research influenced them for deciding of what kind of frame work they will use. $51.05 \%$ of respondent said that concrete is more appropriate base on the ten variables that serve in this research and $58.36 \%$ of respondent choosing better to use concrete base on the ten variables that serve in this research.

\section{PENDAHULUAN}

Dunia konstruksi terus melakukan inovasi selaju perkembangan jaman dari awal pemunculannya. Inovasi ini terus merangkak naik dalam upaya untuk memenuhi tuntutan konsumen akan bangunan yang kokoh dan murah pada awalnya. Namun seiring berkembangnya kebutuhan manusia akan kehidupan yang lebih dari sekedar cukup, bangunan kini dituntut untuk dapat memuaskan kebutuhan akan kemewahan pada manusia yaitu dari segi arsitektur dan fasilitas-fasilitas lain yang tercakup dalam suatu bangunan. Berkembang mulai dari bangunan yang terbuat dari gua yaitu batu yang dilubangi, candi batu yang disusun dan dilekatkan , bilik yaitu anyaman dari tumbuhan bambu, kayu yang disusun rapat, hingga kini terus berubah menjadi bangunan batu beton dan baja yang kuat dan tahan lama. 
Semua bangunan yang kini ditempati, membutuhkan rangka yang kuat dan fleksibel untuk menjaga agar bangunan tetap kokoh dalam waktu yang sangat lama, dan membuat suatu bangunan dibutuhkan biaya yang sangat mahal serta waktu yang cukup lama sebelum bangunan dapat digunakan dengan layak.

Dimasa sekarang ini, rangka bangunan yang digunakan ada dua macam, yaitu konstruksi rangka beton dan rangka baja. Keduanya digunakan sesuai dengan kelebihan dan kekurangannya. Kelebihan-kelebihan yang dimiliki keduanya menjadi alasan mengapa salah satunya dipilih dari pada yang lainnya oleh pemilik bangunan, sedangkan kekurangan-kekurangannya merupakan resiko yang harus ditanggung bersama baik untuk pihak pemilik, konsultan, kontraktor, pelaksana hingga mandor dan tukang, yang tentunya resiko ini sesuai dengan tanggung jawab mereka masing-masing.

Hal ini menimbulkan pertanyaan tentang pertimbangan dasar dalam memilih rangka yang sesuai dengan bangunan yang diinginkan. Untuk itulah penulis ingin mengangkat hal ini untuk dijadikan masalah demi mencapai penyelesaian untuk kepentingan bersama, dengan mengkaji apa saja pertimbangan yang mempengaruhi dalam mengambil keputusan struktur rangka yang sebaiknya digunakan serta sejauh mana pertimbangan tersebut mempengaruhi.

\section{METODA}

Penelitian ini bertujuan untuk mengetahui faktor-faktor apa yang menjadi pertimbangan para konsultan perencana dalam mengambil keputusan struktur rangka yang akan digunakan serta seberapa banyak faktor-faktor yang menjadi variabel pada penelitian ini mempengaruhi konsultan perencana dalam melakukan kegiatan konstruksi pada bangunan-bangunan di Tangerang.

Tempat penelitian adalah di wilayah Kota Tangerang, dan waktu penelitian adalah dimulai pada April 2007 sampai dengan Juli 2007.

Metode penelitian yang akan digunakan pada penelitian ini adalah metode wawancara, studi literatur dan metode survai dengan teknik analisis data statistik deskriptif. 
Pada penelitian ini yang akan menjadi populasi adalah seluruh konsultan yang sedang menjalankan proyek konstruksi di Kota Tangerang-Banten. Dari hasil survai didapat bahwa jumlah calon responden sebanyak 77 orang.

Sampel pada penelitian ini adalah calon responden yang memenuhi persyaratan sebagai responden, sesuai dengan pembatasan masalah pada bab I. Jumlah sampel yang dapat dianalisa sebanyak 37 orang.

Dari hasil presurvey dan studi literatur yang dilakukan sebelumnya, didapat variabel-variabel yang menjadi faktor dalam pemilihan struktur rangka beton dan struktur rangka baja. Faktorfaktor tersebut adalah:

1. Biaya

2. Jadwal (waktu)

3. Perawatan bangunan

4. Nilai bangunan setelah tidak digunakan

5. Pengadaan material

6. Kemudahan pengerjaan

7. Ketahanan akan suhu tinggi (kebakaran)

8. Iklim

9. Asuransi

10. Kemungkinan model

Pada kuesioner yang akan dibuat, variabel-variabel tersebut akan dialokasikan pada nomornomor soal. Untuk lebih jelasnya mengenai alokasi variabel pada kuesioner di jelaskan pada table dibawah ini.

Tabel 4. Keterangan variabel pada kuesioner

\begin{tabular}{|l|l|l|l|l|}
\hline \multirow{2}{*}{$\begin{array}{l}\text { No } \\
\text { variabel }\end{array}$} & Nama variabel & No soal \\
\cline { 3 - 5 } & & Pengaruh & $\begin{array}{l}\text { Struktur } \\
\text { yang } \\
\text { lebih baik }\end{array}$ & Penggunaan \\
\hline 1 & $\begin{array}{l}\text { Nilai ekonomis bangunan setelah tidak } \\
\text { digunakan }\end{array}$ & 1 & 2 & 3 \\
\hline 2 & Kemudahan pelaksanaan & 4 & 5 & 6 \\
\hline 3 & Kebakaran & 7 & 8 & 9 \\
\hline 4 & Iklim & 10 & 11 & 12 \\
\hline
\end{tabular}




\begin{tabular}{|l|l|l|l|l|}
\hline \multirow{2}{*}{$\begin{array}{l}\text { No } \\
\text { variabel }\end{array}$} & Nama variabel & No soal & \multicolumn{2}{l|}{} \\
\cline { 3 - 5 } & & Pengaruh & $\begin{array}{l}\text { Struktur } \\
\text { yang } \\
\text { lebih baik }\end{array}$ & Penggunaan \\
\hline 5 & Asuransi & 13 & 14 & 15 \\
\hline 6 & Kemungkinan model bangunan & 16 & 17 & 18 \\
\hline 7 & Biaya & 19 & 20 & 21 \\
\hline 8 & Pengadaan material & 22 & 23 & 24 \\
\hline 9 & Perawatan bangunan & 25 & 26 & 27 \\
\hline 10 & Waktu & 28 & 29 & 30 \\
\hline 11 & $\begin{array}{l}\text { Nilai ekonomis bangunan setelah tidak } \\
\text { digunakn }\end{array}$ & 1 & 2 & 3 \\
\hline
\end{tabular}

1. Instrumen pengambilan data

Instrumen yang akan digunakan pada penelitian ini adalah kuesioner yang akan diberikan kepada responden.

Validitas dan Reliabilitas

Uji keabsahan dalam penelitian, sering ditekankan pada uji validitas dan reliabilitas. Data yang valid adalah data "yang tidak berbeda" antara data yang dilaporkan oleh peneliti dengan data yang sesungguhnya terjadi pada objek penelitian, sedangkan data yang reliabel pada penelitian kualitatif adalah data yang konsisten dan stabil.

a. Validitas

Validitas merupakan derajat ketepatan antara data yang terjadi pada objek penelitian dengan daya yang dapat dilaporkan oleh peneliti (Sugiyono, 2005). Dalam penelitian kualitatif, temuan atau data dapat dinyatakan valid apabila tidak ada perbedaan antara yang dilaporkan peneliti dengan apa yang sesungguhnya terjadi pada obyek yang diteliti. Tetapi perlu diketahui bahwa kebenaran realitas pada penelitian kualitatif tidak bersifat tunggal, tetapi jamak.

b. Reliabilitas

Menurut penelitian kualitatif, suatu realitas itu bersifat majemuk/ganda, dinamis/selalu bergerak, sehingga tidak ada yang konsisten, dan berulang seperti semula.

Analisis data kualitatif adalah bersifat induktif, yaitu suatu analisis berdasarkan data yang diperoleh, selanjutnya dikembangkan menjadi hipotesis. Dalam penelitian ini hipotesis yang dimaksud adalah kesimpulan yang menggambarkan keadaan pada objek penelitian di lapangan. 
Pada penelitian kualitatif, analisis data dilakukan sejak sebelum masuk ke lapangan, selama di lapangan dan setelah selesai di lapangan.

1. Analisis sebelum di lapangan

Pada penelitian ini dilakukan presurvey untuk mendapatkan data sebelum memasuki lapangan. Data ini berupa hasil wawancara terhadap calon-calon responden, yang kemudian menghasilkan varibel-variabel yang nantinya digunakan untuk menentukan fokus penelitian.

\section{Analisis selama di lapangan}

Analisis di lapangan dilakukan pada saat pengumpulan data dalam periode tertentu. Bila jawaban dirasa masih kurang memuaskan, maka akan dilakukan penelitian lanjutan sampai data dianggap kredibel.

\section{Analisis setelah selesai dari lapangan}

Setelah data dianggap cukup maka tahap selanjutnya adalah pengambilan kesimpulan.

Kuesioner

Kuesioner dibuat dengan sebelumnya penulis melakukan wawancara dengan para konsultan perencana mengenai faktor-faktor yang menjadi pertimbangan dalam mengambil keputusan jenis struktur rangka yang akan digunakan. Dari hasil wawancara kemudian didapat faktor-faktor tersebut yang kemudian akan menjadi kuesiner yang akan diberikan kepada responden.

Studi literatur dilakukan untuk mendapat dasar atas hasil wawancara yang sebelumnya dilakukan. Setelah itu dibuat kuesioner berdasarkan hasil wawancara dan studi literatur.

Setelah kuesioner dibuat dan disetujui oleh kedua dosen pembimbing, maka kuesiner tersebut siap disebarkan.

Pengumpulan Data

Kuesioner diberikan kepada responden yaitu para Konsultan Perencana yang sedang melaksanakan proyek konstruksi. Responden juga harus pernah melaksanakan proyek konstruksi dengan struktur rangka beton dan struktur rangka baja. Bila pada proyek tersebut tidak memakai jasa Konsultan Perencana maka yang menjadi responden adalah perencana atau pengambil keputusan struktural yang biasa disebut dengan expert atau kontraktor freelance non company, namun juga harus memenuhi persyaratan-persyaratan seperti para konsultan 
perencana yang memenuhi syarat untuk menjadi responden, dimana syarat-syaratnya seperti yang dijelaskan pada pembatasan masalah pada bab I.

Kuesioner disebarkan di Kota Tangerang, penyebaran dilakukan pada 15 Juni sampai dengan 7Juli 2007. Penyebaran dilakukan dengan sebelumnya melakukan survei pada proyek bangunan yang masih dalam masa konstruksi dan meminta data konsultan perencana atau pengambil keputusan struktural pada proyek tersebut. Kemudian penulis menghubungi konsultan perencana tersebut dan meminta mereka untuk menjadi responden pada penelitian ini. Setelah para responden bersedia untuk mengisi kuesioner yang telah dibuat, penulis menyerahkan kuesioner kepada responden dan setelah beberapa hari kuesioner penulis mengambil kembali kuesioner yang telah diisi oleh responden.

\section{HASIL DANPEMBAHASAN}

\section{A. Tabulasi Data}

Kota Tangerang terbagi atas beberapa wilayah yaitu Tangerang, Batuceper, Benda, Jatiuwung, Cipondoh, dan Ciledug. Jumlah kuesioner yang disebarkan sebanyak 77 buah dan kembali kepada penulis sebanyak 54 buah dan jumlah kuesioner yang bisa ditabulasi dan dipersentasekan sebanyak 37.

Kuesioner yang diterima ditabulasi berdasarkan jenis bangunan yang sedang dikerjakan oleh para responden sebagai berikut:

Tabel 5. Tabulasi Jenis Proyek

\begin{tabular}{|l|l|l|}
\hline No & Jenis bangunan & Jumlah \\
\hline 1 & Ruko & 7 \\
\hline 2 & Rumah ibadah & 8 \\
\hline 3 & Mall & 2 \\
\hline 4 & Kantor & 8 \\
\hline 5 & Show room & 6 \\
\hline 6 & Pabrik & 3 \\
\hline 7 & Sekolah & 3 \\
\hline Jumlah & & 37 \\
\hline
\end{tabular}




\section{B. Analisa}

\section{Persentase jawaban kuesioner}

Isi kuesioner terdiri atas 3 jenis pertanyaan, yang pertama yaitu pengaruh faktor yang dijadikan variabel dalam mempertimbangkan jenis struktur rangka yang digunakan, jika responden menjawab tidak, maka pertanyaan mengenai variabel tersebut selesai dan responden dapat melanjutkan pada pertanyaan mengenai variabel selanjutnya. Jika responden menjawab ya, maka responden dapat melajutkan ke jenis pertanyaan selajutnya pada variabel yang sama.

Jenis pertanyaan kedua mengenai manakah diantara jenis struktur rangka beton dan baja yang dianggap lebih baik berdasarkan variabel tersebut.

Yang ketiga adalah, jika responden telah memilih struktur yang dianggap lebih baik maka struktur rangka yang manakah yang digunakan. Jawaban responden pada jenis pertanyaan yang ketiga ini bisa saja tidak sesuai dengan jawaban yang dipilih pada jenis pertanyaan yang kedua, hal ini disebabkan bahwa pengaruh dari veriabel yang dimaksud tidak terlalu besar sehingga membuat responden tidak memilih untuk menggunakan struktur rangka yang dianggap lebih baik pada variabel tersebut.

Jawaban dari kuesiner yang telah diterima kemudian ditabulasi, sebagai berikut:

Jawaban responden pada jenis pertanyaan yang pertama yaitu mengenai pengaruh variabel pada pertimbangan responden dalam memutuskan jenis rangka yang digunakan, disajikan pada gambar dan tabel dibawah ini.

Tabel 6. Jawaban Responden Pada Jenis Pertanyaan Pertama

\begin{tabular}{|c|c|c|c|}
\hline No variabel & No soal & \multicolumn{2}{|c|}{ Pengaruh } \\
\cline { 3 - 4 } & & $\begin{array}{c}\text { Ya } \\
(\%)\end{array}$ & $\begin{array}{c}\text { Tidak } \\
(\%)\end{array}$ \\
\hline 1 & 1 & 70.2 & 29.7 \\
\hline 2 & 4 & 81.08 & 18.92 \\
\hline 3 & 7 & 67.56 & 32.43 \\
\hline 4 & 10 & 16.22 & 83.78 \\
\hline 5 & 13 & 5.41 & 94.59 \\
\hline 6 & 16 & 94.59 & 5.41 \\
\hline 7 & 19 & 70.2 & 29.7 \\
\hline 8 & 22 & 72.97 & 27.03 \\
\hline 9 & 25 & 78.37 & 21.62 \\
\hline 10 & 28 & 78.37 & 21.62 \\
\hline \multicolumn{2}{|r|}{ Persentase total } & 63.45 & 36.48 \\
\hline
\end{tabular}


Dari tabel jawaban responden di atas, dapat dipersentasekan berdasarkan 10 varibel yang ada, seperti digambarkan pada pie diagram di bawah ini:

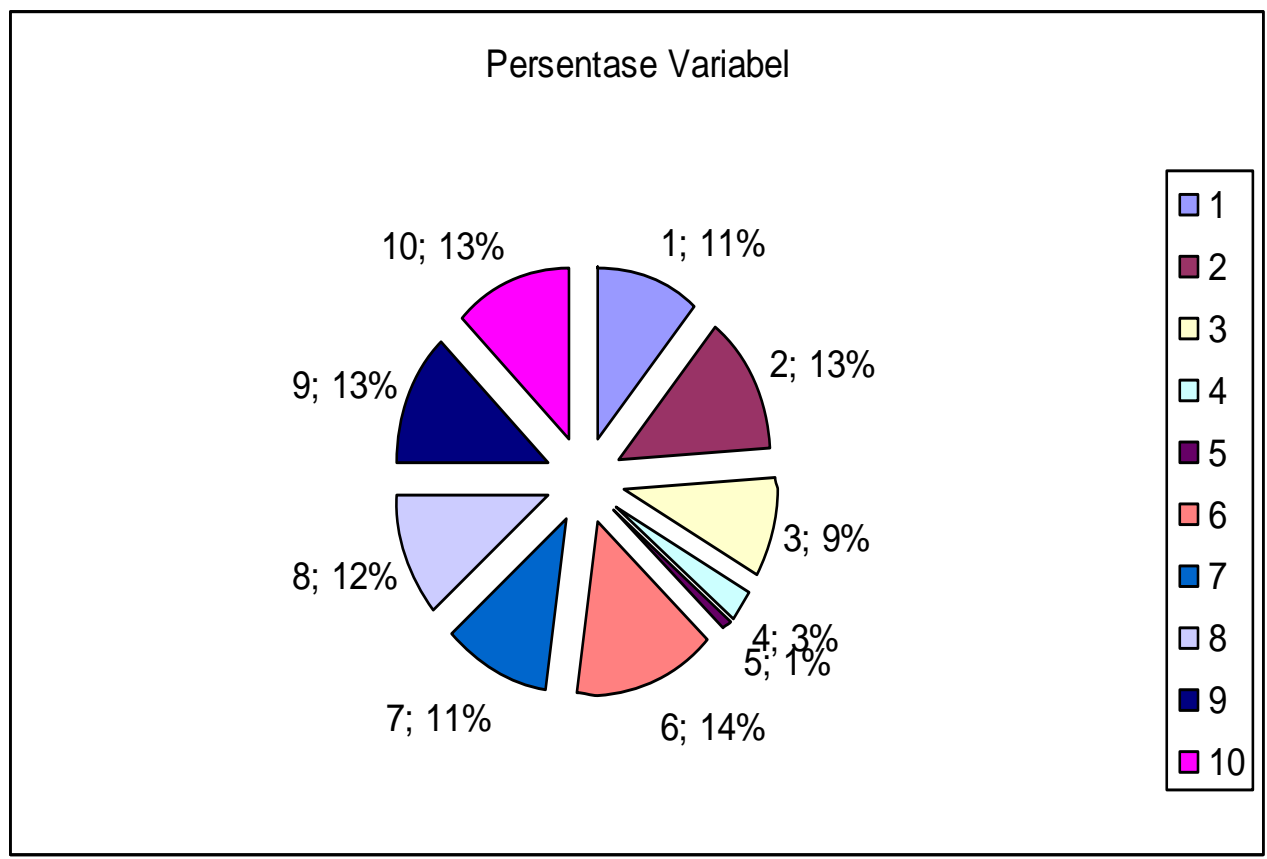

Gambar 2. Persentase Variabel Yang Berpengaruh

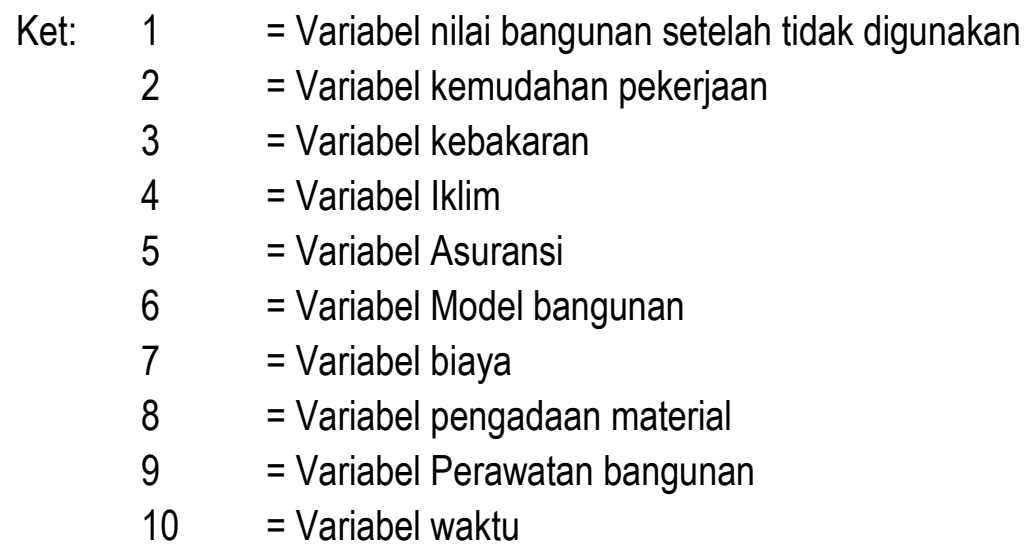

Jawaban responden pada jenis pertanyaan yang kedua yaitu mengenai manakah jenis struktur yang dianggap lebih baik pada tiap variabel, disajikan pada tabel dibawah ini. 
Tabel 7. Jawaban Responden Pada Jenis Pertanyaan Kedua

\begin{tabular}{|l|l|l|l|}
\hline \multirow{2}{*}{$\begin{array}{l}\text { No } \\
\text { variabel }\end{array}$} & \multirow{2}{*}{ No soal } & \multicolumn{2}{|l|}{ Struktur yang dianggap lebih baik } \\
\cline { 3 - 4 } & & Beton (\%) & Baja (\%) \\
\hline 1 & 2 & 3.54 & 96.15 \\
\hline 2 & 5 & 36.66 & 63.33 \\
\hline 3 & 8 & 88 & 12 \\
\hline 4 & 11 & 16.67 & 83.33 \\
\hline 5 & 14 & 100 & 0 \\
\hline 6 & 17 & 74.28 & 25.72 \\
\hline 7 & 20 & 53.84 & 46.16 \\
\hline 8 & 23 & 85.18 & 14.8 \\
\hline 9 & 26 & 68.96 & 31.04 \\
\hline 10 & 29 & 3.45 & 96.55 \\
\hline Persentase total & 53.05 & 46.91 \\
\hline
\end{tabular}

Jawaban responden pada jenis pertanyaan yang ketiga yaitu mengenai manakah jenis struktur yang dipilih untuk digunakan berdasarkan tiap variabel, disajikan pada tabel dibawah ini.

Tabel 8. Jawaban Responden Pada Jenis Pertanyaan Ketiga

\begin{tabular}{|l|l|l|l|}
\hline \multirow{2}{*}{$\begin{array}{l}\text { No } \\
\text { variabel }\end{array}$} & No soal & \multicolumn{2}{|l|}{ Pemilihan struktur } \\
\cline { 3 - 4 } & & $\begin{array}{l}\text { Beton } \\
(\%)\end{array}$ & Baja (\%) \\
\hline 1 & 3 & 30.76 & 69.24 \\
\hline 2 & 6 & 40 & 60 \\
\hline 3 & 9 & 80 & 20 \\
\hline 4 & 12 & 16.67 & 83.33 \\
\hline 5 & 15 & 100 & 0 \\
\hline 6 & 18 & 74.28 & 25.72 \\
\hline 7 & 21 & 53.84 & 46.16 \\
\hline 8 & 24 & 77.77 & 22.23 \\
\hline 9 & 27 & 62.08 & 37.94 \\
\hline 10 & 30 & 48.27 & 51.72 \\
\hline Persentase total & 58.36 & 41.64 \\
\hline
\end{tabular}


Untuk lebih jelasnya mengenai gambaran hasil persentase jawaban responden pada masingmasing variabel, dijelaskan pada gambar diagram di bawah ini.

a. Nilai bangunan setelah tidak digunakan.

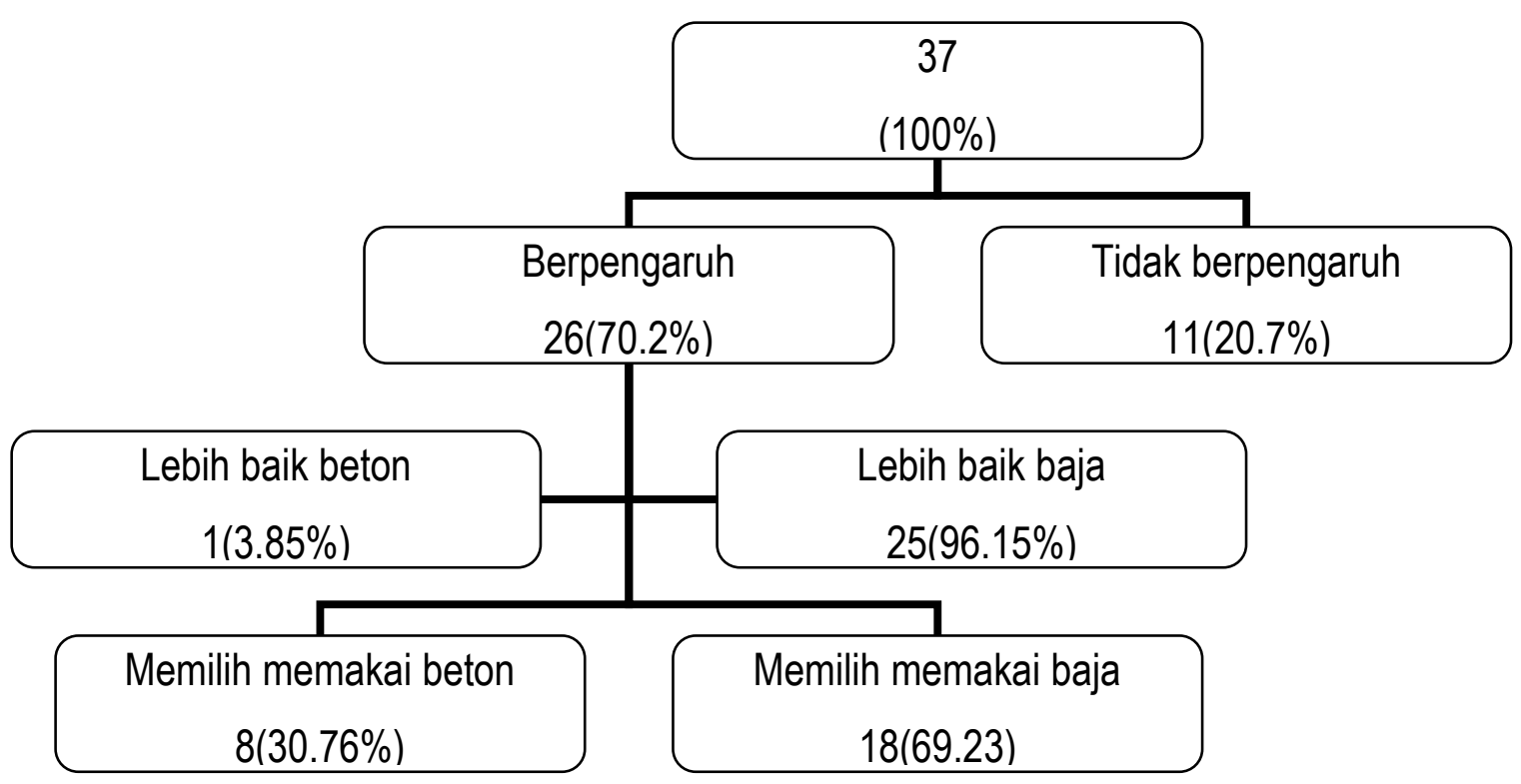

Gambar 3. Skema jawaban responden pada variabel 1

$70,2 \%$ responden mengatakan bahwa nilai bangunan setelah tidak terpakai merupakan salah satu faktor yang mempengaruhi dalam mengambil keputusan tentang jenis struktur rangka yang akan digunakan.

Dari 70,2 \% responden yang menjawab ya, 96,15\% responden mengatakan bahwa struktur rangka baja memiliki nilai ekonomis yang lebih tinggi dibandingkan struktur rangka beton setelah bangunan tidak lagi digunakan.

$69,24 \%$ responden memilih menggunakan struktur rangka baja karena memiliki nilai bangunan tak terpakai lebih tinggi dibandingkan beton. 
b. Kemudahan pelaksanaan pekerjaan

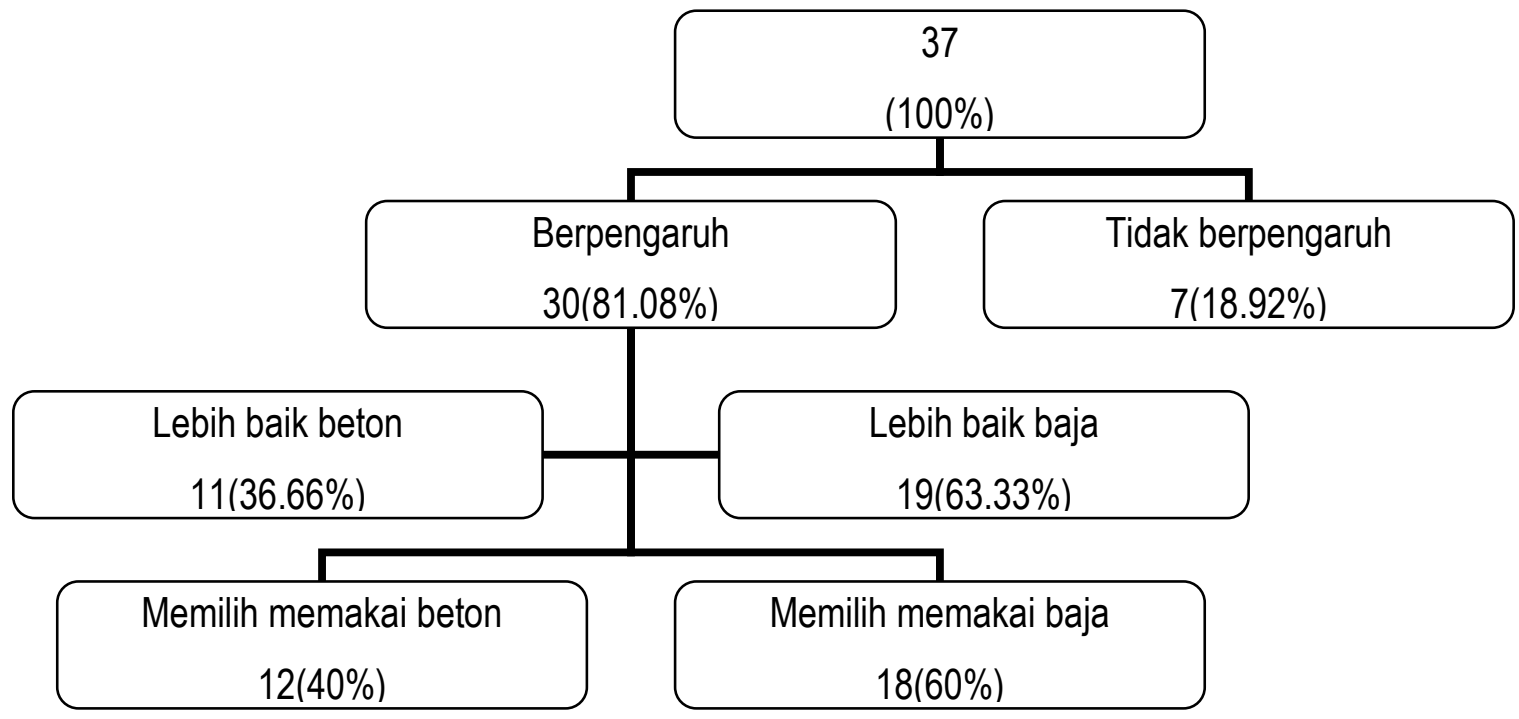

Gambar 4. Skema jawaban responden pada variabel 2

$81.08 \%$ responden mengatakan bahwa kemudahan dalam pelaksanakan pekerjaan struktur mempengaruhi dalam mengambil keputusan jenis struktur rangka yang akan digunakan.

Dari $81.08 \%$ responden yang menjawab ya, $63.33 \%$ responden mengatakan bahwa struktur rangka baja lebih mudah pelaksanaannya dibandingkan dengan pelaksanaan pekerjaan struktur rangka beton.

$60 \%$ responden memilih menggunakan struktur rangka baja karena pengerjaannya lebih mudah.

c. Ketahanan suhu tinggi (kebakaran)

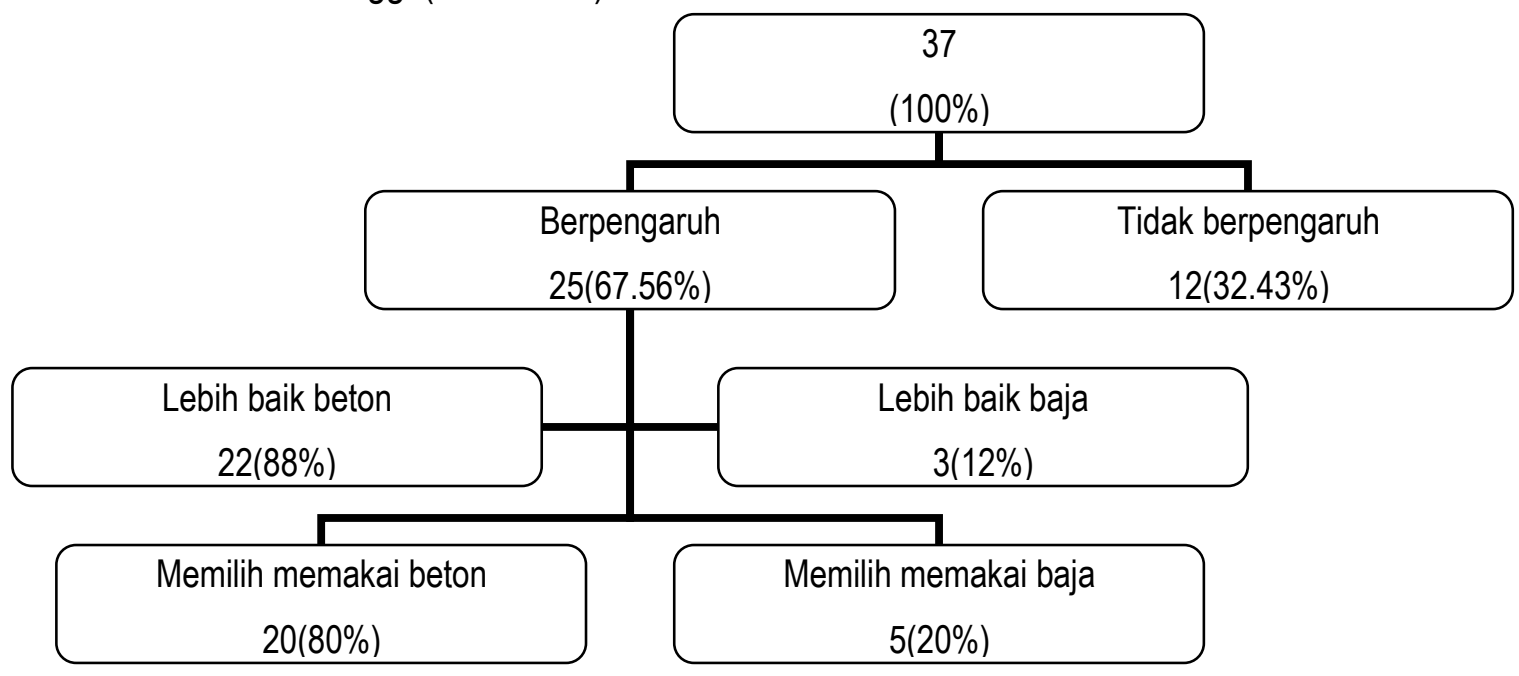

Gambar 5. Skema jawaban responden pada variabel 3 
67,56\% responden mengatakan bahwa ketahan suatu struktur rangka menjadi salah satu faktor yang mempengaruhi dalam mengambil keputusan tentang jenis rangka yang akan digunakan Dari $67,56 \%$ responden yang menjawab ya, 91,89\% responden mengatakan bahwa struktur rangka beton lebih tahan terhadap suhu tinggi dibandingkan dengan struktur rangka baja.

$80 \%$ responden memilih untuk menggunakan struktur rangka beton karena beton lebih tahan terhadap suhu yang tinggi seperti kebakaran.

d. Iklim

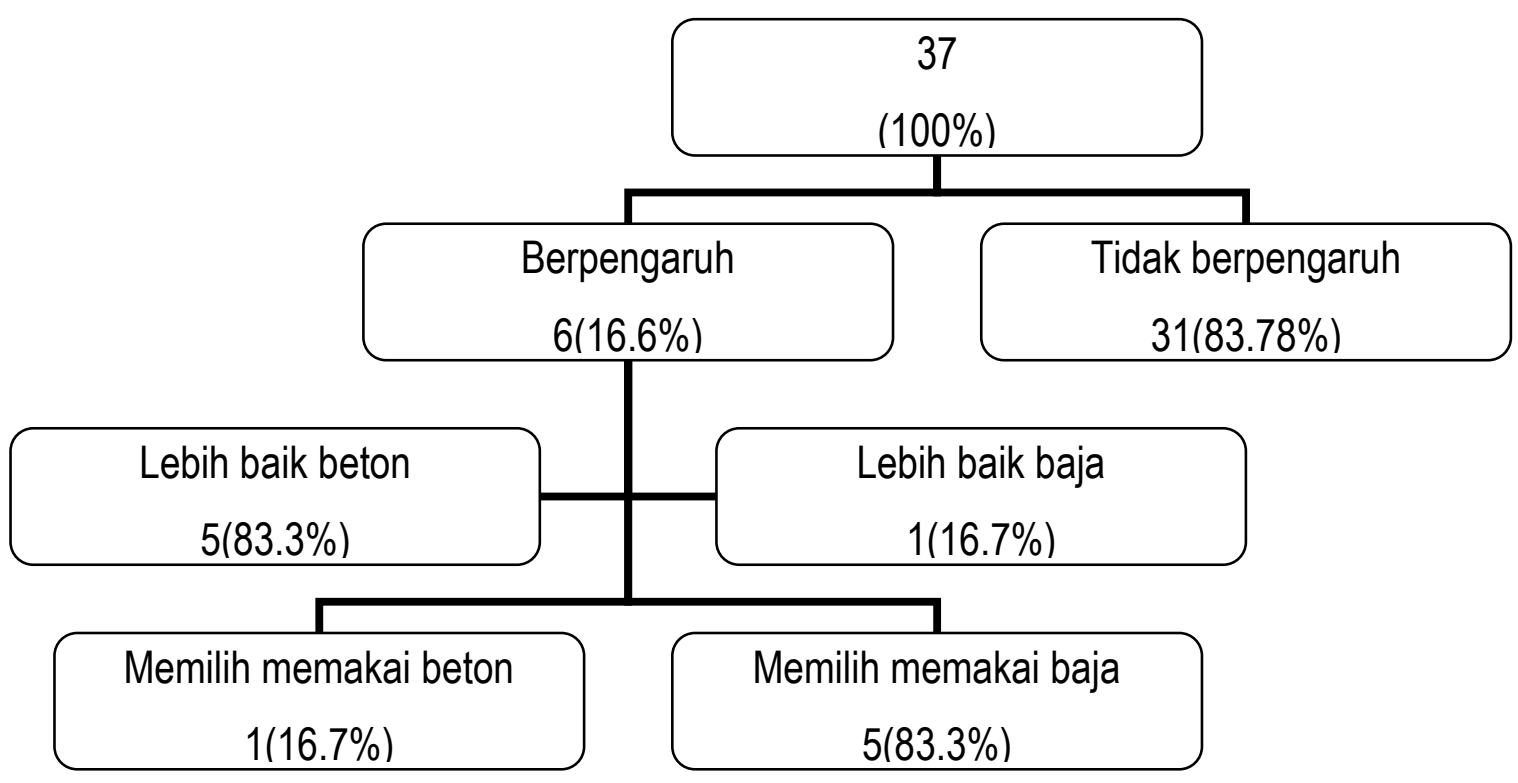

Gambar 6. Skema jawaban responden pada variabel 4

83,78\% responden mengatakan bahwa iklim di Kota Tangerang tidak mempengaruhi pertimbangan dalam memutuskan jenis struktur rangka yang digunakan

Dari $83.78 \%$ responden yang menjawab ya, $83.3 \%$ responden menjawab bahwa struktur rangka beton lebih sesuai dengan iklim di Kota Tangerang. Namun $83.3 \%$ responden memilih menggunakan struktur rangka baja dari pada struktur rangka beton. 
e. Asuransi

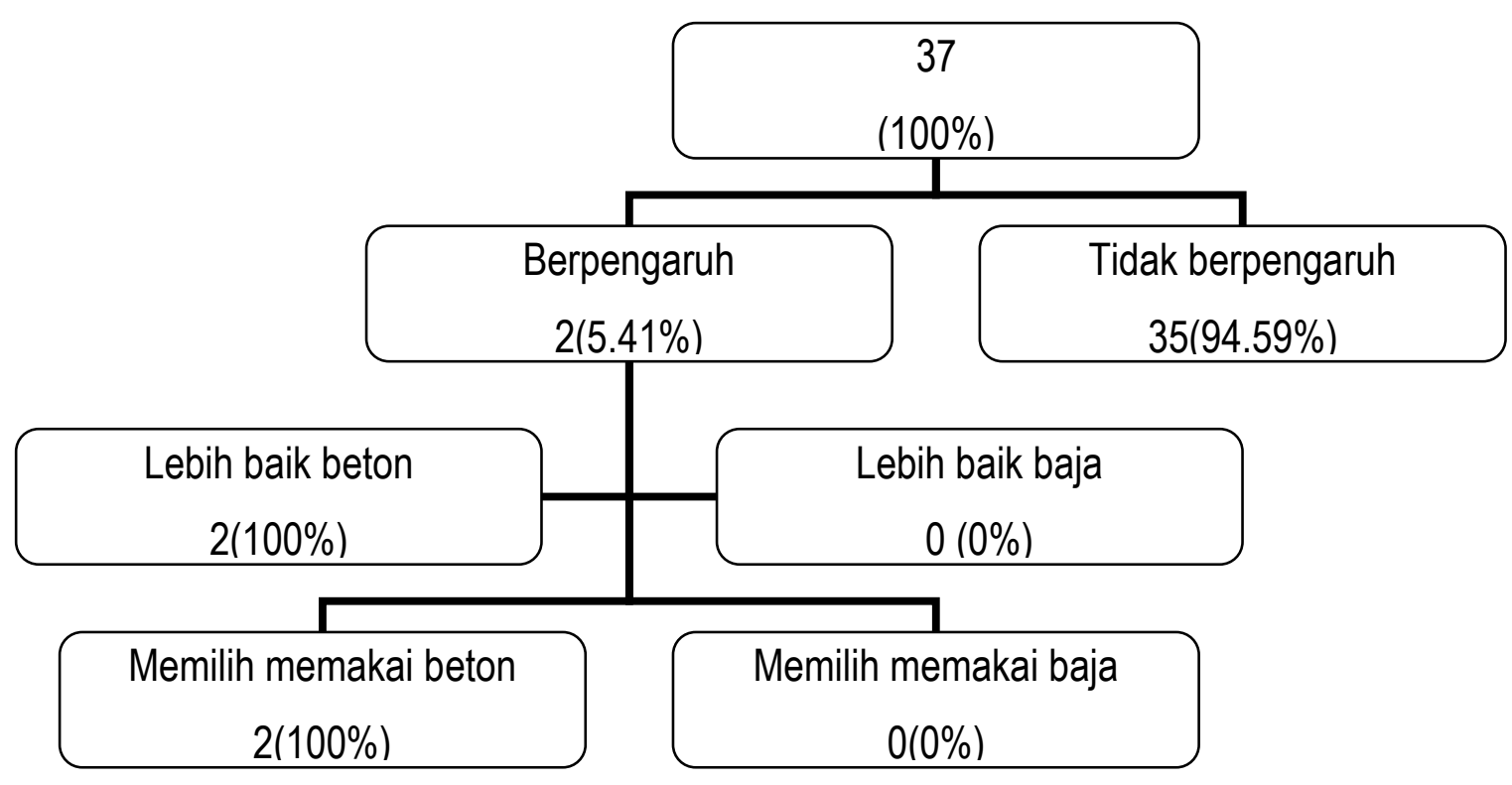

Gambar 7. Skema jawaban responden pada variabel 5

94,59\% responden mengatakan bahwa asuransi menjadi bukan salah satu faktor yang mempengaruhi pertimbangan dalam mengambil keputusan jenis rangka yang akan digunakan.

Dari $5.41 \%$ responden yang menjawab ya, 100\% responden menjawab bahwa struktur rangka beton lebih menguntungkan dalam hal pengasuransian dibandingkan baja.

$100 \%$ responden memilih untuk menggunakan struktur rangka beton, karena lebih menguntungkan dalam pengasuransian.

\section{f. Model bangunan}

94,59\% responden mengatakan bahwa kemungkinan suatu struktur rangka dapat dibuat dengan model tertentu menjadi salah satu faktor yang menjadi pertimbangan dalam mengambil keputusan jenis struktur rangka yang akan digunakan.

Dari 94,59 responden yang menjawab ya, $74,28 \%$ mengatakan bahwa struktur rangka beton lebih memungkinkan untuk dapat membuat model bangunan tertentu dibandingkan struktur rangka baja.

$74,28 \%$ responden memilih untuk menggunakan struktur rangka beton karena lebih mungkin dan mudah untuk dibentuk dengan model tertentu. 


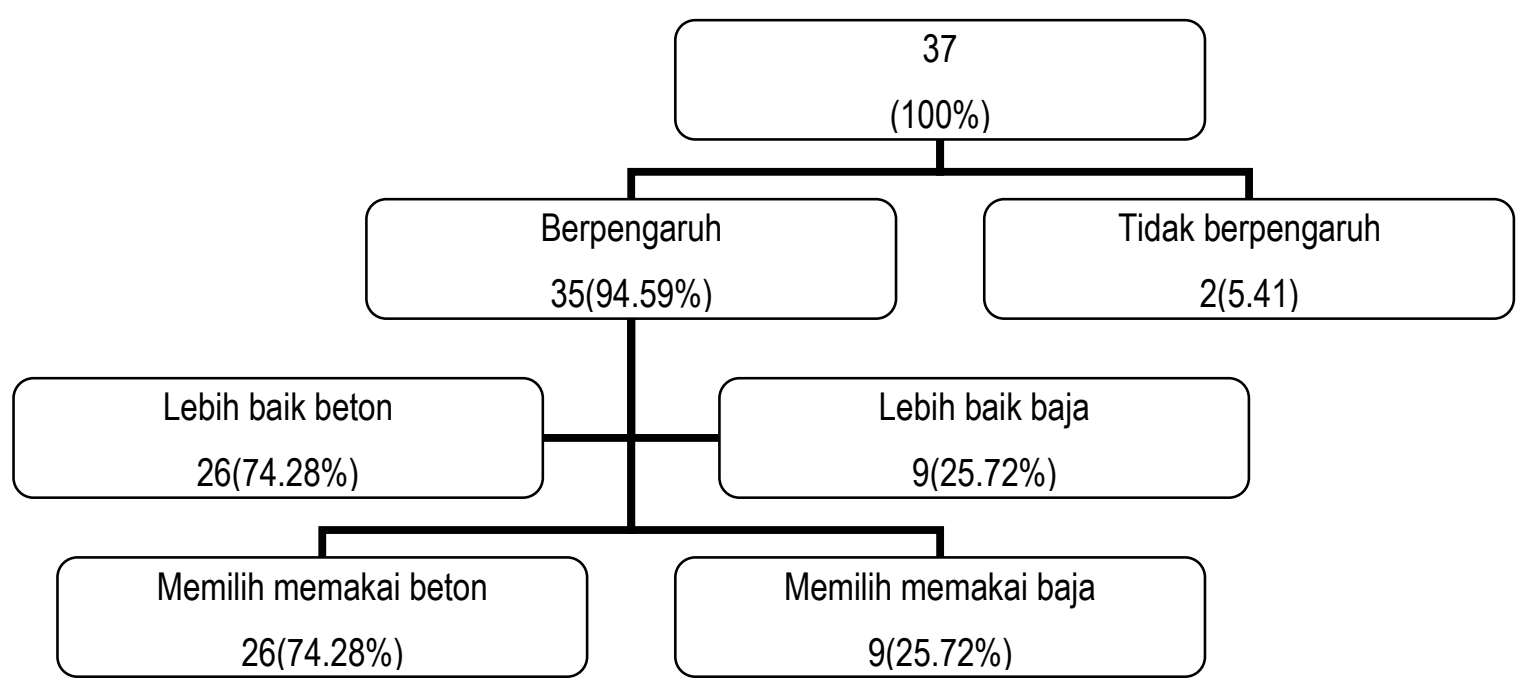

Gambar 8. Skema jawaban responden pada variabel 6

g. Biaya per satuan luas

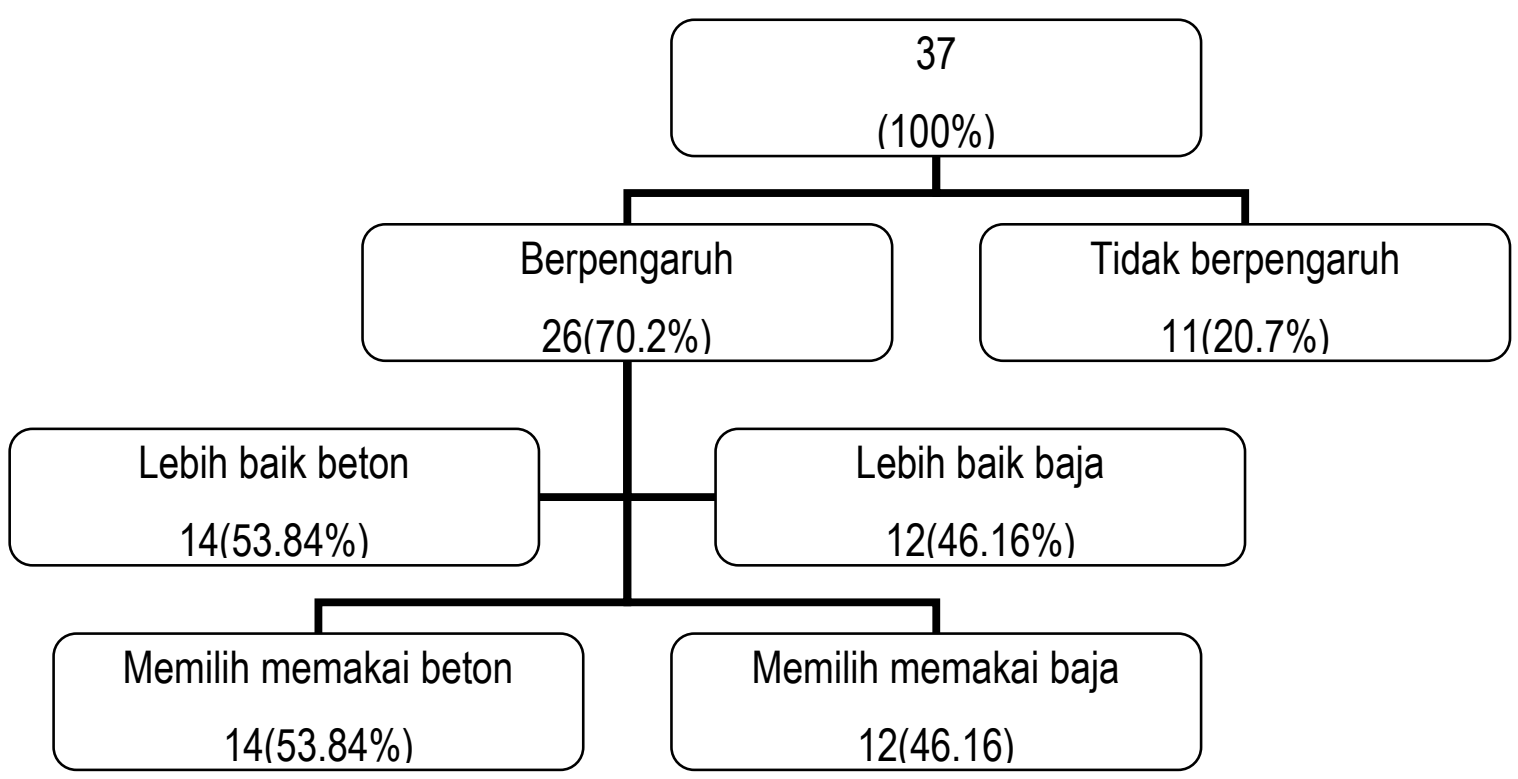

Gambar 9. Skema jawaban responden pada variabel 7

$70,2 \%$ responden mengatakan bahwa harga per satuan luas pembuatan struktur rangka menjadi salah satu faktor yang mempengaruhi pertimbangan dalam mengambil keputusan jenis struktur rangka yang akan digunakan 
Dari $70,2 \%$ responden yang menjawab ya, 53,84\% responden mengatakan bahwa struktur rangka beton lebih murah pelaksanaannya dibandingkan struktur rangka baja.

$53.84 \%$ responden memilih menggunakan struktur rangja beton karena lebih murah dibandingkan struktur baja.

h. Pengadaan material

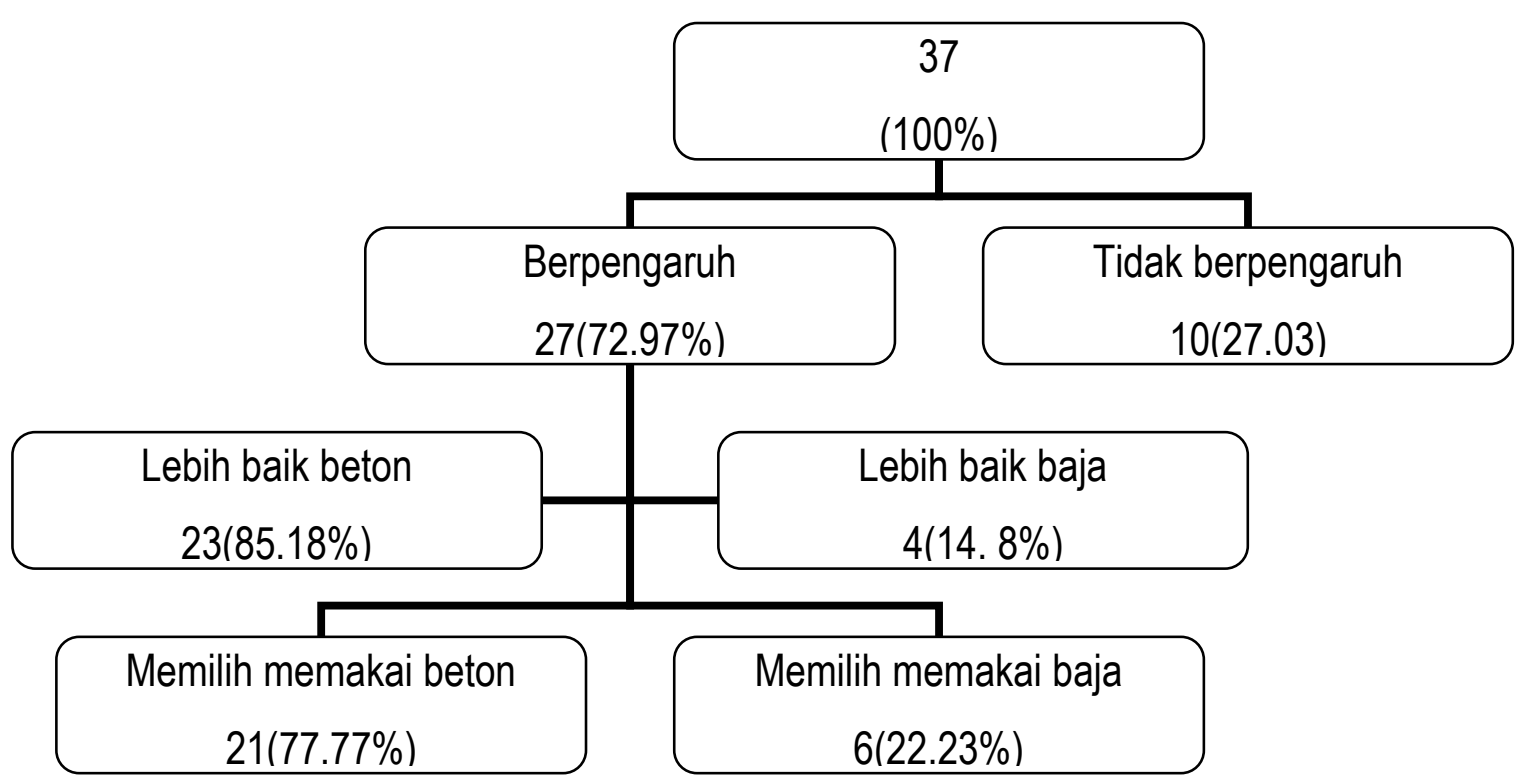

Gambar 10. Skema jawaban responden pada variabel 8

$72,97 \%$ responden mengatakan bahwa kemudahan dalam pengadaan material menjadi salah satu faktor yang mempengaruhi dalam mengambil keputusan jenis rangka yang akan digunakan Dari $72,97 \%$ responden yang menjawab ya, $85,18 \%$ responden mengataskan bahwa struktur rangka beton lebih mudah pengadaan di Kota Tangerang

$77,77 \%$ responden memilih menggunakan struktur rangka beton karena lebih mudah dalam pengadaan material dibandingkan dengan pengadaan material untuk struktur rangka baja.

\section{i. Perawatan bangunan}

$78,37 \%$ responden mengatakan bahwa kemudahan/kesulitan dalam merawat bangunan menjadi pertimbangan dalam mengambil keputusan tentang jenis rangka yang digunakan

Dari $78.37 \%$ responden yang menjawab ya, $68.96 \%$ responden mengatakan bahwa perawatan struktur rangka beton lebih mudah dibandingkan dengan struktur rangka baja. 
$62,06 \%$ responden memilih untuk menggunakan struktur rangka beton karena perawatannya lebih mudah.

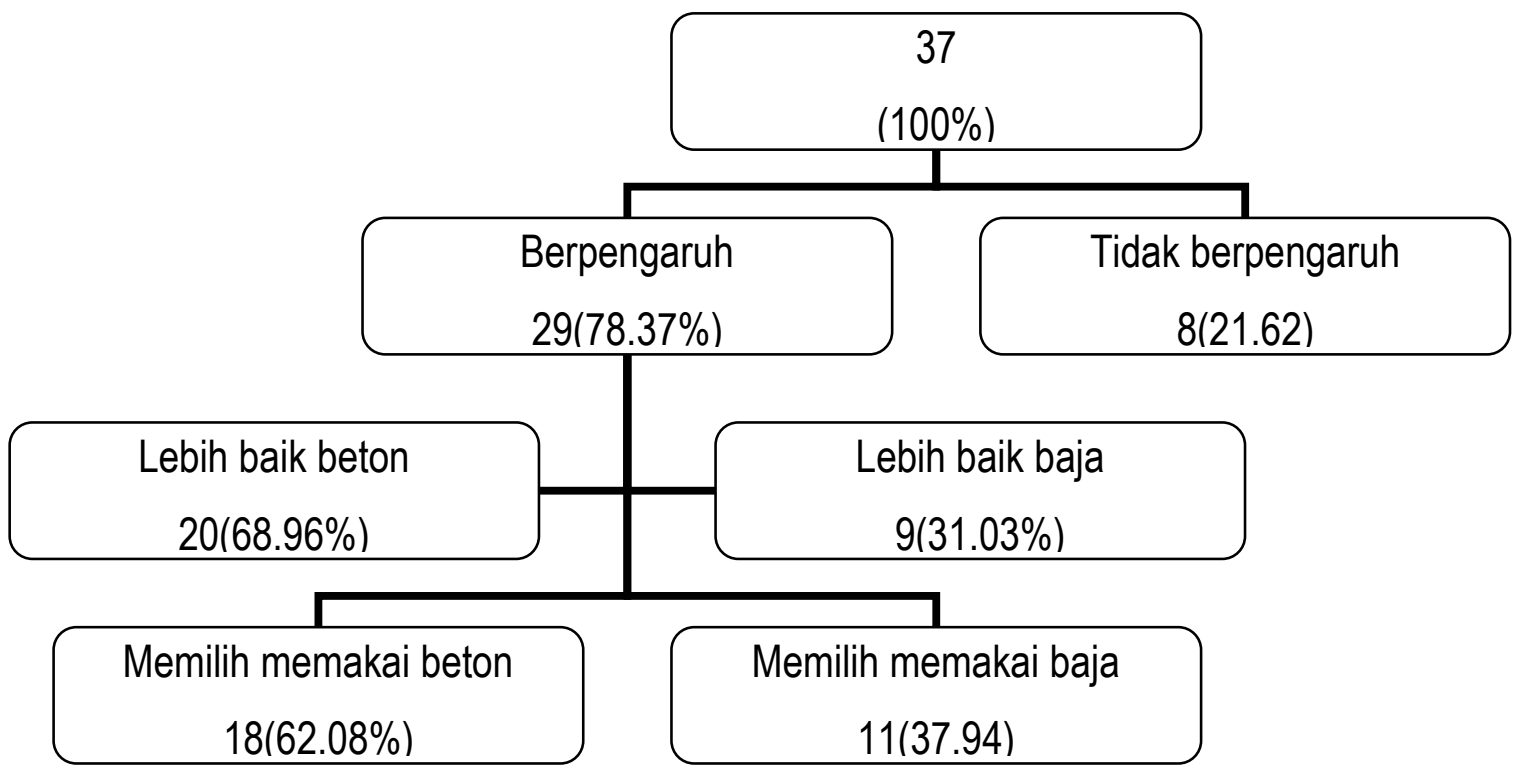

Gambar 11. Skema jawaban responden pada variabel 9

j. Waktu

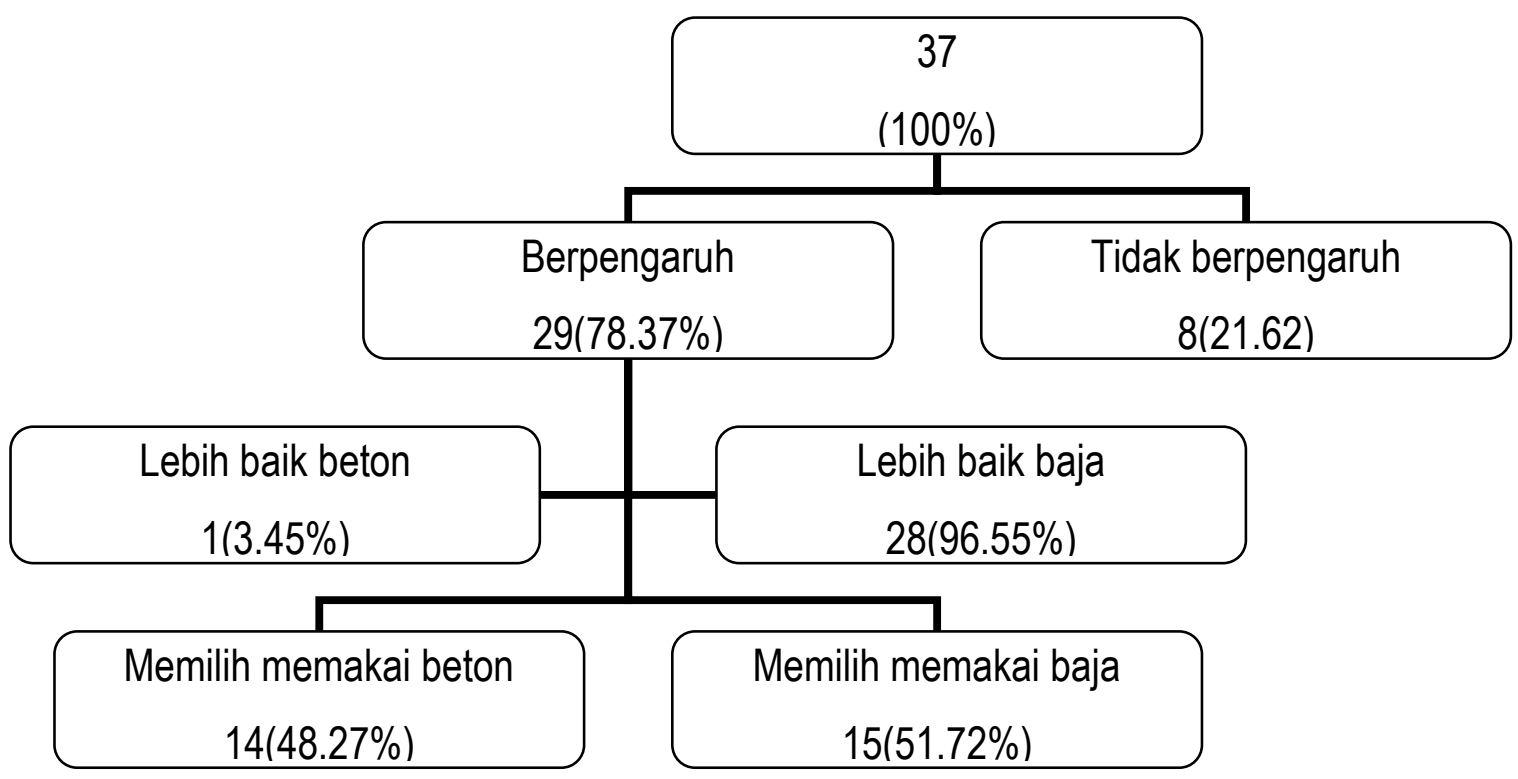

Gambar 12. Skema jawaban responden pada variabel 10

78,37\% responden mengatakan bahwa waktu pelaksanaan struktur rangka menjadi salah satu faktor dalam pertimbangan jenis struktur rangka yang digunakan. 
Dari $78.37 \%$ responden yang menjawab ya, $96.55 \%$ responden mengatakan bahwa struktur rangka baja membutuhkan waktu yang lebih sedikit dibandingkan struktur rangka beton.

$51.72 \%$ responden memilih untuk menggunakan struktur rangka baja karena waktu pelaksanaannya lebih cepat.

\section{Hasil wawancara}

Dalam penelitian ini penulis juga melakukan wawancara langsung dengan para responden. Wawancara dilakukan setelah responden menjawab kuesioner yang diberikan oleh penulis.

Wawancara dilakukan dalam rangka memastikan jawaban yang telah diberikan oleh responden dan menanyakan alasan-alasan perbedaan jawaban pada jenis pertanyaan yang kedua dan ketiga, yang nantinya tersaji pada sub-bab temuan.

Namun wawancara tidak dapat dilakukan terhadap semua responden pada penelitian ini. Hal ini disebabkan oleh kesibukan dan ketidak bersediaan responden untuk meluangkan waktu dalam kegiatan wawancara.

Dari hasil wawancara yang dilakukan didapat, bahwa:

- Keadaan tanah juga mempengaruhi pemilihan struktur rangka

- Kebutuhan akan bangunan dengan bentang lebar juga sangat mempengaruhi pemilihan struktur rangka

- Pada proyek pemerintahan dimana owner (pemilik) adalah pemerintah daerah Kota Tangerang, pemilihan struktur telah dilakukan oleh pihak tersebut dan terkadang konsultan perencana tidak dapat menolak keinginan dari pihak owner walaupun dinilai keputusan tersebut kurang baik.

- Baik struktur rangka beton maupun baja dapat memenuhi segala bentuk/jenis bangunan yang diinginkan, namun pertimbangan yang paling mendasar adalah biaya.

\section{Hasil Temuan Pada Penelitian}

Pada penelitian ini ditemukan jawaban-jawaban pada jenis pertanyaan kedua tidak sesuai dengan jawaban responden pada jenis pertanyaan ketiga. Hal ini kemudian ditindak lanjuti dengan kegiatan wawancara dengan responden untuk mendapatkan alasan mengapa hal ini bisa terjadi. 
Pada variabel 4 yaitu variabel iklim, hasil persentase pada jawaban dari jenis pertanyaan kedua adalah $83.3 \%$ responden menjawab bahwa beton adalah struktur rangka yang sesuai untuk iklim di Kota Tangerang, namun dengan persentase yang sama yaitu 83.3\% responden memilih untuk menggunakan baja sebagai struktur bangunannya.

Menurut hasil wawancara mengenai hal ini, bahwa alasan iklim yang sesuai dengan Kota Tangerang tidak cukup signifikan untuk mempengaruhi responden dalam memilih jenis struktur yang digunakan. Walaupun variabel ini menjadi salah satu pertimbangan oleh responden, namun variabel atau lasan lain lebih mempengaruhi.

Hal ini tidak hanya terjadi pada variabel iklim, namun juga terjadi pada variabel-variabel lain. Terlihat pada hasil persentase jawaban pada jenis pertanyaan kedua dan ketiga yang berbeda, seperti variabel 1 (nilai bangunan setelah tidak digunakan), variabel 2 (kemudahan pelaksanaan), variabel 3 (kebakaran), variabel 8 (pengadaan material), variabel 9 (perawatan bangunan) dan variabel 10 (waktu).

\section{KESIMPULAN}

1. Hasil dari penelitian ini adalah bahwa faktor yang disajikan pada kuesioner cenderung untuk mempengaruhi pertimbangan konsultan perencana dalam memutuskan jenis struktur yang akan digunakan sebesar $63.63 \%$.

2. Penelitian juga menunjukan dari faktor-faktor yang disajikan cenderung bahwa di Kota Tangerang sebaiknya menggunakan struktur rangka baja. Besar kecenderungan tersebut adalah $53.05 \%$.

3. Namun dari hasil penelitian ini juga didapat bahwa faktor-faktor yang disajikan dalam kuesioner cenderung bahwa konsultan perencana lebih memilih menggunakan struktur rangka beton. Besarnya kecenderungan ini sebanyak $58.36 \%$.

\section{DAFTAR PUSTAKA}

Adiyono, Menghitung Konstruksi Beton. Jakarta: Griya Kreasi, 2006

Aji, Firman B., Perencanaan Dan Evaluasi. Jakarta: Bumi aksara,1982. 
Amon, Rene, Perencanaan Konstruksi Baja Untuk Insinyur dan Arsitek I. Jakarta: Pradnya Paramita, 1988.

Departemen Pemukiman dan Prasarana Wilayah, Metode, Spesifikasi dan Tata Cara. Jakarta:Badan Penelitian dan Pengembangan,2002

Departemen Pendidikan Nasional, Kamus Besar Bahasa Indonesia. Jakarta:Balai Pustaka,2002.

Dipohusodo, Istimawan, Manajemen Proyek dan konstruksi. Yogyakarta: Kanisius,1996.

Mulyono, Tri, Teknologi Beton, Yogyakarta: Andi, 2003.

Potma, A.P., Konstruksi Baja: Teori, Perhitungan dan Pelaksanaan. Jakarta: PT. Pradnya Paramita, 1994.

Salvadori, Mario, Disain Struktur Dalam Arsitektur. Jakarta:Erlangga,1992.

Schueller, Wolfgang, Struktur bangunan Bertingkat Tinggi. Bandung: PT. Eresco,1983.

Sulaiman, A., Korosi Baja Pada Struktur Bangunan. Bandung: Asosiasi Korosi Indonesia, 1983.

Sugiono, Memahami Penelitian Kualitatif. Bandung:Alfabeta,2005

Suharto, Iman, Manajemen Proyek. Jakarta: Erlangga, 1994.

T., Gunawan dan Margareth S., Konstruksi Beton Jilid I: Teori Soal dan Penyelesaian. Jakarta: Delta Teknik Group.

Taylor, Harold L., Manajemen Waktu. Jakarta: Bina Rupa Aksara, 1990. 